\title{
Multicultural Education Based On Local Education In Elementary School
}

\author{
Hengki Dwi Juliantoํㅡ, Waspodo Tjipto Subroto²
}

\begin{tabular}{l} 
ARTICLE INFO \\
\hline Article History: \\
Received 19.12.2018 \\
Received in revised form \\
15.03 .2019 \\
Accepted \\
Available online 01.07.2019
\end{tabular}

\begin{abstract}
The purpose of this study is to describe multicultural education based on local wisdom in elementary schools. The type of research used is descriptive qualit ative. The research location is in Balun State Elementary School, Lamongan Regency. Data sources in the study were explored through research subjects, namely principals, teachers, and students. Methods of data collection using interviews, observation and documentation. Dat a are analyzed through data reduction, data presentation and conclusion drawing. Research results are reflected in the initial steps of the teacher preparing himself as an educat or by transforming himself in order to become a multicultural person. The two nuances of the school that uphold tolerance. Third the learning process always pays attention to the individual and respects dignity, dignity and freedom in thinking. Fourth coaching tolerance. Fifth, inter-religious harmony. The six local values are implemented in the design of learning and action. Based on the data analysis, theconclusions about the process of multicultural education in Balun State Elementary School 1 Lamongan include: 1) multicultural education planning, 2) implementation of multicultural education and local wisdom-based multicultural education strategies.
\end{abstract}

Keywords:

(C) IJERE. All rights reserved

Multicultural education, local wisdom, elementary school.

\section{INTRODUCTION}

The times and conditions of today's society are more active and quick to follow modernization unconsciously also have an impact on weakening and the lack of public understanding of various local values of corruption that can affect such as attitudes, thought patterns and actions of both individuals and groups. The lack of understanding of local wisdom can trigger potential in a conflict both sara and race. Siriat and Nurbayan (2018, p.151) The condition of the people in Indonesia with a variety of local wisdom in each region should have both individuals and groups to be able to understand, do and maintain as a guide in various activities in life to create an environment that has comfort, care, regularity, mutual respect for the differences that exist around them. If a local wisdom is not maintained and safeguarded one of which is through education for the younger generation it is alleged that it can trigger degraded local culture by modernization. In the era of globalization, modernization of human beings slowly began to have an apathy with the values of local wisdom as part of the multicultural nation in culture. With the existence of local wisdom in each region, the community should be required to be able to maintain as a guideline in life in order to create an order, care for humans, the environment, and natural resources around them (Cecep \& Permana, 2006).

With regard to existing conditions and as an effort to overcome problems related to local culture, an educational role is needed. The education referred to in this context is the existence of local-based multicultural education as an effort to create a nation that is moral, virtuous, ethical, and tolerant. Multicultural education itself as described by Banks in Multicultural Education Handbook of Research is: that "multicultural education is a concept, frame work, a philosophical view point, a way of thinking, a value orientation, and a set of educational needs of culturally diverse student populations

Banks, (2001). It means that multicultural education is a concept of either ideas or philosophy as a set of believe and an explanation that recognizes and assesses the importance of cultural and ethnic diversity in shaping lifestyles, social experiences, personal identities, educational opportunities from individuals, groups and countries. As with the conditions in Balun State Elementary School 1, the school environment and the multicultural conditions of the surrounding community with various local cultural wisdom make this school very interesting by creating a condition for schools that apply multicultural education based on local

\footnotetext{
Corresponding e-mail:hengkyjuliant007@gmail.com,orcid.org/0000-0002-8198-9353

2 Corresponding e-mail:waspodosubroto@unesa.ac.id

Posgraduate Universitas Negeri Surabaya ${ }^{1}$, Universitas Negeri Surabya ${ }^{2}$
} 
expertise in the place Hilda Hernandez (Choirul Mahfud, 2010, p.176) states multicultural education as a perspective that recognizes the social, economic, and political realities experienced by each individual in a complex and diverse human encounter, and reflects the importance of culture, race, sexuality, gender, religion, socio-economic status, and exceptions in the education process. In this view, education should provide space for the transformation of the knowledge and values of multiculturalism by creating respect for the diverse realities of students. On the other hand, local wisdom-based multicultural education must be able to lead individuals, students and the community to become human beings who are concerned with the culture of their region. Not only to the extent that, with the application of multicultural education based on local wisdom students are expected to become achievers. The values of local wisdom which are cultures in an area have an influence to make students as achievers as far as exposure by (Nieto, 2000). It is important to examine the ways in which culture can affect learning and achievement in school.

Afifah, (2017). Then it is supposed that multicultural education based on local wisdom must be taught to students through integrated learning in each subject. Or on the other hand things that are considered more appropriate are done by incorporating the value of local wisdom in learning local content a nd being applied in schools and the social environment. Of course with the aim of teaching the values of local wisdom in multicultural education in order to provide understanding for students to have a broader understanding, and to accept differences from various aspects of life

\section{METHOD}

In this study the research method used is through a qualitative approach that is with the type of descriptive qualitative research. The data sources are obtained from primary data sources and secondary data sources. Data collection techniques using the method of observation, interviews, and documentation. For data analysis using the analysis of Milez and Huberman (2005). The collected data is in the form of words analyzed by reducing, presenting data, and drawing conclusions. The overall results are then summarized by taking the essence and writing it with standard sentences

\section{RESULTS}

Multicultural education based on local wisdom has an important role in providing understanding, learning, aw areness, for students related to matters relating to the values of local wisdom in their area. Based on the findings of the research at SDN Balun 1 Lamongan through observation, interviews and documentation, the research findings were obtained as in the following table:

\begin{tabular}{|c|c|c|}
\hline No & Rese & $\operatorname{Re}$ \\
\hline 1. & $\begin{array}{l}\text { How is the application of local } \\
\text { wisdom-based multicultural } \\
\text { education in Balun State } \\
\text { Elementary School } 1 \text { Lamongan? }\end{array}$ & $\begin{array}{l}\text { The findings of the study on the application of local wisdom- } \\
\text { based multicultural education in Balun State Elementary School } \\
\text { 1 Lamongan include: } \\
\text { 1) preparation of teachers as educators who have an } \\
\text { understanding of the concepts and paradigms of } \\
\text { multicultural education } \\
\text { 2) the creation of a multicultural oriented climate that promotes } \\
\text { social justice for students } \\
\text { 3) making, syllabus, lesson plans, and learning tools whose } \\
\text { contents and processes teach and incorporate values of local } \\
\text { wisdom in multicultural education } \\
\text { 4) school institutions cooperate with each other in multicultural } \\
\text { education }\end{array}$ \\
\hline .2. & $\begin{array}{l}\text { What is the implementation of } \\
\text { local wisdom-based multicultural } \\
\text { education in students at Balun } \\
\text { State Elementary School } 1\end{array}$ & $\begin{array}{l}\text { Based on the results of observations made on the } \\
\text { implementation of multicultural education in Balun State } \\
\text { Elementary School } 1 \text { Lamongan can be seen from several of } \\
\text { them: }\end{array}$ \\
\hline
\end{tabular}




\begin{tabular}{|c|c|c|}
\hline & Lamongan & $\begin{array}{l}\text { 1) Environmental Atmosphere Schools that are very } \\
\text { multicultural and uphold tolerance amidst a school } \\
\text { environment that has a diversity of both culture and religion. } \\
\text { 2) multicultural education based on local wisdom through } \\
\text { formal education, which pays attention to individual } \\
\text { students and respects dignity, dignity, and freedom in } \\
\text { thinking } \\
\text { 3) Guidance on tolerance that is carried out by the teacher in } \\
\text { fostering student tolerance through attitudes to support the } \\
\text { celebration of diversity, establish communication and set an } \\
\text { example for students } \\
\text { 4) Inter-Religious Harmony in Students at Balun State } \\
\text { Elementary School 1Lamongan which is shown by a tolerant } \\
\text { attitude and an attitude of appreciation for various religious } \\
\text { activities. }\end{array}$ \\
\hline 3. & $\begin{array}{l}\text { What is the local wisdom-based } \\
\text { Multicultural Education Strategy at } \\
\text { Balun State Elementary School } 1 \\
\text { Lamongan? }\end{array}$ & $\begin{array}{l}\text { Based on the results of research conducted so that an } \\
\text { understanding of multiculturalism can be understood and } \\
\text { applied, it needs to be sought through a strategy including: } \\
\text { 1) the application of multicultural based learning designs. such } \\
\text { as formulating learning objectives teacher orientation leads } \\
\text { to affective and psychomotor aspects that contain a network } \\
\text { of cooperation between students by using the cooperative } \\
\text { learning approach } \\
\text { 2) the teacher shows a fair attitude, is patient in guiding and } \\
\text { eliminating prejudice in other groups that are different both } \\
\text { religious and cultural. } \\
\text { 3) the values of local wisdom as a basis for multicultural } \\
\text { education such as religion, tolerance and mutual cooperation } \\
\text { are absorbed and implemented by the teacher as a model in } \\
\text { elementary school education. }\end{array}$ \\
\hline
\end{tabular}

\section{DISCUSSION}

Based on the findings of research on multicultural education based on local wisdom in Balun State Elementary School 1 Lamongan then discussed and described as described in the descriptive qualitative analysis technique (exposure) from the data that has been obtained both through observation, interviews and documentation, the results of the research related research are as following:

\section{A. Planning for Multicultural Education in Balun State Elementary School 1Lamongan}

One of the elements that needs special attention as a step to implement local-based multicultural education is the teacher, because the teacher is an actor who is directly dealing with students. Therefore the teacher must have an adequate understanding of the concepts and paradigms of multicultural education. It needs to be emphasized to the teacher and all staff at Balun State Elementary School 1 that multicultural education is not only about introducing other cultures to students, but the important thing to do is the creation of a multicultural oriented climate that promotes social justice for students with the aim of preparing students being a citizen who is able to carry out community reconstruction can serve the needs of groups, especially groups that are different. The initial step of teachers' efforts to prepare themselves as educators 
and teachers of multicultural education is to carry out a self-transformation in order to become a multicultural person such as the teacher can regarding his identity, and how the attitude towards his students is diverse both religion, socio-economic background, culture and abilities. In this stage the teacher must be able to find an answer, affirming the commitment to treat students fairly regardless of different religions, cultures, ethnicities and backgrounds.

The next plan is the making, syllabus, lesson plan, and learning tools that the contents and process of the teacher also teach or incorporate the values of local wisdom in Balun village during the learning activities to support multicultural education which are also loaded from the objectives, materials, methods, models, media and evaluations. Then a multicultural education plan can be created when organizing school institutions work together to design and also build a very strong foundation, so that students can learn safely and comfortably as well as to support the diversity of fellow Indonesian citizens

\section{B. Implementation of Multicultural Education for Students at Balun State Elementary School 1 Lamongan}

The implementation of multicultural education includes the planting of attitudes in order to understand, live together and have solidarity with diversity and differences. Based on the principal's explanation that the goal of multicultural education is to instill mutual respect, sincerity and tolerance for cultural diversity in the community. In connection with this, in the teacher's learning should convey and instill the value of being tolerant, respecting and respecting the diversity of the implementation of multicultural education in Balun State Elementary School 1 Lamongan can be seen from several things including:

\section{1) The atmosphere of the school environment}

SDN 1 Balun Lamongan has a very multicultural nuance and highly upholds tolerance amid a tolerant Balun community. This can be seen from students who have different religions ranging from Islam, Christianity and Hinduism. Besides that, Balun State Elementary School 1is surrounded by various places of worship which are very close to the mosque, the church and also pure ones which are very close to the school grounds. All school people are very friendly, it seems that students from different forms of religion are not awkward to play together even with others who are just known such as greeting and speaking language, polite behavior and respectful attitude.

\section{2) Local wisdom-based multicultural education through formal education}

The implementation of religious education in Balun State Elementary School 1 Lamongan school, students are classified according to class in general except when religious studies which will be classified based on their respective religions, so that when the religious learning process takes place in schools students get the same portion of religious education. From the results of these observations it $w$ as found that in Balun State Elementary School 1 Lamongan all students received the same portion of religious education.

The learning process in teaching and learning activities always pays attention to individual students and respects dignity, and freedom of thought as a means of expressing opinions, so that students learn is a fun thing and at the same time encourages their personality to develop optimally. As when implementing religious learning in schools, students enter based on their respective religions, but if there are students who want to learn about other religions, they are still welcome as a new knowledge.

\section{3) Coaching tolerance}

From the results of observations made by researchers obtained information that communication betw een teachers and students, teachers with teachers, and students with students at Balun State Elementary School 1 is very family. In communicating with students, the teacher does not look at his religion. Every time you meet the teacher, both the students and the students always shake hands. Likewise between students and students, whether religious or not they play together, eat together and do other activities together. From the results of the observation it was obtained information that the efforts made by the teacher in fostering 
Julianto,H.D. \& Subroto,W.T. (2019).Multicultural education based on local education in elementary school. International Journal of Educational Research Review,4(3), 420-426.

student tolerance include:

a) Supporting religious celebrations involving students of different faiths as the committee.

b) Always communicate with students regardless of religion, race or ethnicity.

c) Teachers as role models by providing good examples of tolerance such as mutual respect for both fellow teachers and students of different religions. The teacher is a field officer as well as a role model in education who is always in direct contact with students.

\section{4) Inter-religious harmony among students in 1 balun lamongan}

Inter-religious harmony is everyone's dream. Every human being hopes for the creation of a peaceful and prosperous life. In order to create a peaceful and prosperous life, it is necessary to create a situation that forms a foundation for tolerance of essential religious harmony. Essential tolerance and harmony in society cannot be created by force. If tolerance and harmony are created by force, then there is only false tolerance and harmony. Essential tolerance and harmony depart from conscience and initiative from all parties involved.

Umi sumbulah and nurajanah (2013) "stated that" inter-religious harmony can be carried out with the following pattern of approaches: first, a sociological approach, here there must be a resolution pattern in dealing with conflict completely so that the settlement of the community is not momentary, but once peacefully resolved forever; second, theological-elitist approach, meaning that religious leaders do not position themselves as elites, but must show good example of faith and practice of religious teachings ". From the observations made by the researcher, it can be concluded that what happened at Balun State Elementary School 1 Lamongan already represented if the existence of school people who were so harmonious were several findings that occurred, such as the location of schools adjacent to places of worship, attitudes of school people who were so tolerant of differences also alw ays appreciates every school activity carried out by school residents at Balun State Elementary School 1 such as slaughtering qurban animals and other diversity activities.

\section{Local Wisdom-Based Multicultural Education Strategy in SDN Balun 1 Lamongan}

Multiculturalism as one of the many things needed by a community, including education to be able to help each other, love each other, improve the degree, intelligence of the nation and humans. Therefore, so that an understanding of multiculturalism can be understood and applied, it is necessary to cultivate it in a strategic way, one of which is through education

The first step taken by the teacher must be the application of multicultural based learning designs. In formulating learning objectives, teacher orientation leads to affective and psychomotor aspects that include a collaboration between students who have different backgrounds. Learning strategies conducted by teachers in Balun State Elementary School 1 Lamongan namely the application of cooperative learning through various variations. From the results of the research carried out proven in this strategy can improve the collaboration between students with diverse backgrounds (Sudrajat, 2011). The learning strategy is also able to reduce prejudice towards other students of different religions and eliminate the exclusivity of students from established economic backgrounds.

Second, each teacher is able to show a fair attitude and eliminate prejudice in other groups. This is very important because students depart from different backgrounds. They come from different groups, religions, ethnicities, socio-economics, and cultures. Then the thing that is done by the teacher as an educator is having an attitude of patience in serving, guiding students especially for those with low abilities or for students having special needs with each background different. Difficult things to do, done by a teacher in determining the achievement of a multicultural education goal. As the pioneer of multicultural education in Geneva Gay (Zamroni, 2011, p.145) saw the importance and necessity of multicultural education is to provide an educational service that improves performance optimally for students who are underdeveloped. 
Thus multicultural education has a holistic perspective not only to provide fair treatment without prejudice but also to be able to maximize achievement for students .

Third, the values of local wisdom in the community around the Balun State Elementary School 1 Lamongan which contain messages, appeals, and advice such as how to behave, behave, religious values, tolerance and mutual cooperation which are then absorbed and implemented by the teacher as a model in multicultural education based on local wisdom that is in line with the school's vision and mission. Multicultural education is then applied by the teacher either through learning or action in interacting with each other inside and outside the school such as respecting, respecting and tolerating differences so that they become examples for students in behaving well in the school environment and society. By doing this research is expected in the future can provide benefits for schools to keep trying to actualize the attitude of multicultural education based on local education in students so that multicultural education based on local education can be embedded properly and internalized in students not only in the school environment but in the home and community.

\section{CONCLUSION}

Moderation in various countries including the Indonesian nation is a serious challenge in maintaining local wisdom. In anticipation and to provide understanding for students related to the importance of maintaining unity, diversity, and values of local wisdom by applying local wisdom-based multicultural education in basic education. Various things that can be done by schools include: 1) multicultural education planning, 2) implementation of local wisdom-based multicultural education, and 3) local wisdom-based multicultural education strategies. Therefore, multicultural education based on local wisdom should be applied early to students. Stakeholders, especially educational institutions must have a strong commitment and high awareness as a step to support the implementation of multicultural education. Furthermore the teacher must be willing to carry out self-transformation and self-reflection in guarding and teaching on a multicultural basis. Teachers need to get a guidance and direction so that they can play a maximum role so that the objectives of multicultural education can be implemented as well as possible. The limitations of this study is that the researcher can not examine the attitude, activity of teacher in more depth because of the limited time in this research. teachers have different characters so the attitude or way of teaching to students is also different and cannot be examined more deeply. Therefore the researchers expect further research to examine the attitudes and activities of teachers about multicultural education based on local education.

\section{REFERENCES}

Ardiansyah,R., Suharno, Triyanto (2018). Inheritancenational culture through learning in elementary school at disruptive era: Case study in Surakarta Indonesia. International Journal of Educational Research Review,3(4),48-53.

Banks, J.A. (2001). Citizenhsip education and diversity: Implication for teacher education. Journal of Teacher Education, 52 (1), 5-16.

Choirul Mahfud. (2010). Pendidikan Multikultural . Yogyakarta: Pustaka Pelajar.

Permana, R. Cecep Eka. (2006). Tata Ruang Masyarakat Baduy. Jakarta: Wedatama Widya Sastra

Creswell, J.W. 2013. Research Design pendekatan kualitatif, kuantitatif, dan mixed, edisi ketiga. Yogyakarta: Pustaka Pelajar.

Emzir. (2012). Metodologi penelitian kualitatif: Analisis Data. Jakarta : Rajawali Pers.

Juwita,W., Abdul Salim, Winarno Winarno (2018). Students' tolerancebehavior in religious-based primary school: Gender perspective. International Journal of Educational Research Review,3 (3),51-58.

Moleong, Lexy J. (2013). Metode penelitian kualitatif. edisi revisi. Bandung: PT. Remaja Rosdakarya.

Miles, Matthew B. \& A. Michael Huberman. (2005) . Qualitative data analysis (terjemahan). Jakarta : UI Press 
Nieto, S. (2000). Placing equity front and center: some thoughts on transforming teacher education for a new century. Journal of Teacher Education, 51(3).

Siriat \& Nurbayan. (2018). Pendidikan multikultural berbasis kearifan lokal dalam pembentukkan karakter sisw a di tanjungpinang provinsi kepualauan riau. Jurnal Pendidikan Ilmu Sosial, Volume 27.

Sudrajat (2011). Pendidikan berbasis multikultural untuk meningkatkan kualitas. Jpsindo No. 1, Volume 1.

Sumbulah, Umi dan Nurjanah. (2013). Pluralisme agama makna dan lokalitas pola kerukunan antar umat beragama. Malang: UIN-Maliki Pers.

Sugiyono.(2010). Metode Penelitian pendidikan pendekatan kuantitatif, kualitatif, dan r\&d. Bandung: Alfabeta.

Zamron. (2011). Pendidikan untuk demo-krasi: Tantangan menuju civil society. Yogyakarta: Bigraf publishing. 